\title{
Examining the Effectiveness of Corporate E-Learning in Global Talent Management
}

\author{
https://doi.org/10.3991/ijac.v10i2.7305 \\ Amy Wong $\left({ }^{\square}\right)$ \\ GlobalNxt University, Kuala Lumpur, Malaysia \\ amy.wongeglobalnxt.edu.my \\ Karin Sixl-Daniell \\ MCI University of Applied Sciences, Innsbruck, Austria
}

\begin{abstract}
The purpose of this study is to examine the effectiveness of corporate e-learning in the context of talent management on a global scale. It begins with a discussion of the importance of talent management, the challenges in global talent management, and the role of corporate e-learning in global talent management. Data collected via an online survey from 74 students (global leaders from a multinational IT provider with more than 90,000 employees across 50 countries) enrolled in a customized corporate e-learning program is presented and discussed. The findings suggest that corporate e-learning can be used to develop talent attributes and skills such as problem solving, analytical, communication, research, and time management skills. Specifically, analytical, communication, and time management skills are important predictors of overall corporate e-learning experience, while analytical and research skills are important predictors of job performance. As part of global talent management, companies can enroll their A-players, high performers or high potentials into relevant corporate e-learning programs that can be used to effectively address the training challenges of a scattered workforce and improve coordination among internal and outside collaborators and partners in complex business processes and projects. The sample for this study was limited to a multinational IT services provider. Future research should extend the scope of data collection to include talents from a variety of organizations, as well as a variety of geographies and industries to further investigate the generalizability of these findings.
\end{abstract}

Keywords - Corporate e-learning, talent management, talent development, IT

\section{$1 \quad$ Introduction}

In recent years, talent management has emerged as a critical success factor in the corporate world due to factors such as globalization, knowledge-based competition, new forms of organization, demographic changes, increased mobility, and changing 
complexity of the workplace [1]. In addition, ongoing transformational changes in global business environments such as the shift from product-based to knowledgebased economies, the need for employees who can handle more complex and relational job roles, and the growing importance of building and sustaining long term customer relationships are affecting the quantity, quality and characteristics of talent needed [2].

Increasingly, corporations are becoming aware of the strategic value and impact of strong talent as a core competitive asset in the global workplace, as they seek to develop and retain the best talents from their key group of employees. These talented employees, with outstanding abilities, and who are highly motivated, should be given ample opportunity to develop themselves to achieve high individual performance, which will eventually contribute to high organizational performance, mediated by work motivation, organizational commitment and extra-role behavior. Highly engaged employees produce better business results than disengaged employees, as seen in outputs such as higher job productivity, improved customer satisfaction and better employee retention [3]. To create competitive advantage and deliver organizational success, firms need to effectively identify and manage the global talent challenges they are confronted with and proactively adapt to these challenges as they evolve and develop [4]. In a world of constant change, these challenges may develop continuously and create problems as the process of training and developing individuals to ensure long-term skill and competence supply in an organization is complex [5]. In an increasingly fast-paced knowledge-driven economy, global talents must be rapidly updated on new developments and information on a regular basis.

As such, it is of paramount importance for corporate talent management to provide the right blend of knowledge at the right time that will improve the effectiveness of their employees' development. Corporate e-learning can be used to effectively implement and develop talent management in global organizations, as corporates can use e-learning to address the training challenges of a globally scattered workforce and to improve coordination among internal and outside collaborators and partners in complex business processes and projects. Moreover, corporate e-learning offers effective, low cost, immediate, consistent and concise training that allows employees to complete training conveniently at off-hours or from home, at their own pace, in an interactive, comprehensive, and engaging manner. This new form of learning offers tremendous opportunities for the multinational companies to train their manpower in required fields related to their work [6].

The purpose of this study is to examine the effectiveness of corporate e-learning in the context of talent management on a global scale. It begins with a discussion of the importance of talent management, the challenges in global talent management, and the role of corporate e-learning in global talent management. Data collected via an online survey from 74 students enrolled in a customized corporate e-learning program is presented and discussed. 


\section{$2 \quad$ Literature Review}

\subsection{The Field of Talent Management}

The field of talent management is a rapidly growing field and has received increased attention in the academic literature in the recent years [7, 8]. Despite this, the implementation of talent management is still in its infancy stage. According to Lewis and Heckman [9], talent management focuses primarily on talent pools and regards talent management as a process to ensure an adequate flow of employees throughout the organization. The authors see a great deal of resemblance with succession planning or human resources planning intended to fill specific, mainly middle to senior management positions. Within this perspective, there are two different points of view: one focuses on high-performing talent or talent with high potential (the recruitment and development of 'A-performers'), while the other states that everyone has their own talents and Human Resources Management should help everyone achieve high performance.

Talent management can be viewed as a transformation process (input, process and output), i.e. where talents are used as input, carefully processed and developed with the appropriate Human Resources Management practices in order to achieve the desired output. Talent management can also be characterized as a positive approach to HRM in which the development and training of the talented employees are emphasized [8]. This study adopts the perspective of Lewis and Heckman [9], where the process of talent management focuses mainly on A-players, high performers or high potentials, and succession planning or human resource planning is undertaken to fill middle to senior management positions.

Global Talent Management. Due to the increased access to much more complex roles on a globalized labor market, corporates invest more and more in their talents so as to maintain the competitive advantage and to develop their organizations. To date, there is no consensus or consistent definition of global talent management [10]. According to Scullion and Collings [11], global talent management includes all organizational activities for the purpose of attracting, selecting, developing, and retaining the best employees in the most strategic roles (those roles necessary to achieve organizational strategic priorities) on a global scale. Global talent management normally equates to around 10 percent of the global workforce, and this includes employees with a track record of high potential and high performance. These employees are likely to fill strategic roles and engage in knowledge transfer and sharing, which have the capacity to impact significantly on business outcomes [10].

On a functional level (Human Resources), global talent management refers to the systematic use of specific Human Resources policies and practices to manage the several global talent challenges that a firm confronts [12]. Adopting this view, talent management is equal to HRM, and the specific aspects of Human Resource policies and practices include issues related to location and relocation management, planning and forecasting, staffing (to include attracting, selecting, retaining, reducing and removing), training and developing, and evaluating employees consistent with an organ- 
ization's strategic directions taking into account the evolving concerns of the workforce and regulatory requirements.

Global talent management focuses on managing an organization's strategic Human Resources issues to ensure the right amount of talent and motivation, at the right place, price, and time. It aims to balance the organization's talent pool with its needs in the short term, and position the organization to have the talents ready in the long term. The success of firms today is dependent on how effectively they identify and manage the many global talent challenges they confront, and adapt to them as they evolve and develop. Indeed, global talent challenges are relevant to today's competitive workforce and such challenges often emerge in the context of a dynamic and changing business environment. Among the many factors that shape the specific challenges of firms are: (a) globalization, (b) changing demographics, (c) demand for workers with needed competencies and motivation, and (d) the supply of those needed competencies and motivation [4].

Despite the challenges of global talent management, effectively developed talented human resources can generate a major competitive advantage for the organization in terms of increased employee job performance, satisfaction, engagement, and motivation, which leads to improved customer satisfaction and better employee retention, and finally increased organizational performance [12]. In view of this, there exists a diversity of HRM strategies that can be used to elaborate, substantiate and implement global talent management within multinational organizations. However, for purposes of this study, examination of global talent management is limited to the specific aspect of talent development.

Corporate e-Learning and Talent Development. According to Garavan et al. [13], the talent development process consists of four broad areas, namely the identification of the talent pool, the design of the development program (i.e., what competencies to develop, length of the program), the evaluation of its effectiveness (i.e., measurement of the program outcome), and the organizational support for the program. An important outcome of the talent development process is the development of competencies and skills needed in the job, and some of the competencies and skills commonly sought after by employers include problem solving and analytical skills, communication and research skills, time management as well as the ability to work with cross-functional teams [14]. For example, a study conducted by the American Management Association pointed to an urgent call for analytics talent across organizations, with companies reporting a preference to build analytics skills through training (47 percent) versus hiring (17 percent) [15]. In a McKinsey study of 1,500 executives across the globe, time management is seen as an organizational priority that needs to be addressed at an institutional level [16].

Another outcome of the talent development process is the transfer of tacit and valuable knowledge across a globally scattered workforce. Various training and development experiences such as sponsorship, coaching, mentoring, and formal talent development programs such as participation in corporate e-learning can act as mechanisms to transfer such information [13]. This study focuses on the examination of corporate e-learning in the talent development process. 


\subsection{Corporate e-Learning}

Technological advances in information and communication technologies have led to the emergence of innovative ways of delivering software and services. Among these innovations are sophisticated e-learning systems that can be used by corporates to effectively train and develop the skills of their human capital through the use of modern communication tools and networking technologies. Considering the growing interest in work-life balance $[17,18,19]$, corporates can use e-learning to carefully balance their training and development needs with their employees' personal and professional lives in an effort to attract the best talent and retain high-potential employees. Retention of talent is seen as a key area and opportunity to maintain a competitive workforce $[20,21]$ and is improved when employees are offered compensation and benefits, have a supportive work culture, can balance work and life activities and can develop and advance [22].

Specifically, e-learning can provide ample opportunities for strengthening training, development, and learning strategies and activities. In addition, corporates can use elearning to address the training challenges of a scattered workforce and improve coordination among internal and outside collaborators and partners in complex business processes and projects. In order to examine the appropriateness of corporate elearning, organizations need to understand the advantages and disadvantages of elearning, both to the corporate and to the employees, as outlined in the following section [23].

The Corporate Perspective. Some of the advantages of e-learning for the corporate include the elimination of costs associated with face-to-face training and development (i.e., travel, lodging, meals), not only in monetary terms, but also in terms of the loss of productivity time as employees spend time away from their jobs in order to participate in the face-to-face training sessions. A study across industries found that corporations saved 50 per cent to 70 per cent of their overall training cost by replacing traditional training with online delivery [24]. In addition, time spent on learning is greatly reduced [25], and retention of learning content and application of the learning to the job increased over traditional methods as learning of relevant content in the online classroom can be applied almost immediately to the workplace environment, given its simultaneous nature [26]. Consistent delivery of the online content is possible, compared to traditional classroom learning, as the training can be pre-recorded and shared with the rest of the class, leading to scalability of e-learning, which can be delivered immediately to numerous learners worldwide. Moreover, with a good learning management system, expert knowledge can be communicated and captured effectively, while updated training information can be disseminated quickly and cost effectively.

Despite the above advantages, there are several disadvantages of e-learning for the corporate, which include the hefty upfront investment and development costs in elearning solutions. This can be alleviated through customized programs by online educational providers. Technology can be a hindrance if the infrastructure of the corporate cannot accomplish the training goals, be it hardware or software. There may also be a cultural barrier in e-learning adoption, depending on the demographics, 
psychographics and the geographical location of the workforce, which may predispose them against using computers, laptops, tablets, or smartphones for e-learning [6].

The Employee Perspective. For the employees, the 24/7 flexible and asynchronous mode of e-learning provides ongoing training conveniently at off-hours or from home. Learners can also self-pace their study progress, catering to their own work-life balance, hence bringing about increased learner satisfaction and success. Not only can the interactive content in a good learning management system captivate and engage the learner, it can also deliver the learning material in a more comprehensive and concise manner and also enables students to get back to materials and concepts previously not well understood. Such form of training is also portable, which makes the learning convenient and on-the-go, especially with the proliferation of network, computers, laptops, PDAs and mobile learning. Further, relevant multimedia tools (i.e., webinars, videos, animation) can be incorporated to enhance transfer of knowledge and aid better recall [6]. On the other hand, technology related issues can cause anxiety and stress among employees due to unfamiliarity with and unavailability of technology. Finally, the lack of face-to-face interaction can be a potential disadvantage due to the impersonality and lack of body language related communication. To a certain extent, this can be overcome with the intensity of peer-to-peer-learning and peer-to-instructor learning in online discussion boards and synchronous sessions such as webinars.

\subsection{Purpose of the Study}

The purpose of this study is to examine the effectiveness of corporate e-learning in the context of talent management on a global scale. Following the literature review, the general hypothesis is formulated: The development of talent attributes and skills (via corporate e-learning) contributes to increased organizational performance in a global context. The following research hypotheses are derived:

$\mathrm{H} 1$ : Corporate e-learning can be used to develop talent attributes and skills such as problem solving, analytical, communication, research, and time management skills.

$\mathrm{H} 2$ : Corporate e-learning can lead to talent development outcomes such as job performance, job satisfaction, job engagement, and job motivation.

\section{Method}

To study talent management, Egerová [1] suggested that the focus should be on surveying employees rather than managers or Human Resource professionals. Following this approach, data is collected via an online survey from 198 students enrolled in two sections of a customized corporate e-learning program. The program consists of the following six modules: Leadership Essentials, International Business Environment, Managing Financial Performance, Marketing/ Customer Relationship Management, Strategic Management for Innovative Businesses, and Entrepreneurship. In order to integrate the learning outcomes of the various modules, students have to 
participate in weekly asynchronous online discussion boards (based upon relevant topics/case studies) for three weeks per module, as well as attend two synchronous webinars per module. They also need to complete a final reflective group project at the end of the course. The online content and the course assessment items are developed by the program's faculty, in close consultation with the Human Resource Department.

The response rate was 37.4 percent, with a total of 74 students responding to the survey after one follow up email sent 3 days later. The students are global leaders from a multinational IT services provider with more than 90,000 employees across 50 countries. The company has a talent management and development program in place, where employees are ranked in terms of performance and competencies via a careful process of internal nomination and screening, resulting in a selected pool of talents being groomed to take up various leadership positions within the corporation. These employees are often referred to as A-players, high performers or high potentials, differentiate from the rest of the workforce by (excellently performing) individuals, positions or functions [9].

Participants were asked to state their perceptions of the course on talent attributes and skills such as problem solving, analytical, communication and research skills, as well as time management on a seven-point Likert scale ranging from " 1 = Strongly disagree" to "7 = Strongly agree". The measures for these variables were adapted from the Graduate Employment Survey [14]. To measure the outcomes of talent development, participants were asked to state their perceptions as a result of the course, on outcomes such as employee job performance, satisfaction, engagement, and motivation on a seven-point Likert scale ranging from " 1 = Strongly disagree" to " $7=$ Strongly agree". Several demographic questions such as age, gender, position, job role, function, and residency were elicited.

Most of the respondents were male $(90.45 \%)$, with the vast majority aged between 35 to 44 years old $(64.86 \%)$. The respondents had been working for the company for slightly over eight years on average and were predominantly Senior Managers (39.19\%) with Managers making up 32.43 percent. Almost a third of respondents worked in IT $(31.94 \%)$, while one sixth $(16.66 \%)$ worked in Project Management, followed by the areas of Business Development and Consulting at 12.5 percent each and Management at 9.72 percent. Other areas included single respondents from HR, Product Management, Quality Assurance, Research, Sales, Strategy/Planning, Design, Customer Service and Analysts. Most of the respondents (75.34\%) resided in India, while 10.96 percent and 8.2 percent resided in the US and the UK respectively. Other countries of residence included Canada, Germany, the Netherlands and South Africa.

\section{$4 \quad$ Results and Analysis}

When surveyed about talent attributes and skills acquired from e-Learning, 70.27 percent of the respondents agreed or strongly agreed that the course discussion boards and assignments helped them improve their analytical skills. Likewise, 65.75 percent 
of respondents agreed or strongly agreed that the course helped them improve their problem solving skills.

When asked whether they acquired better research skills as a result of the course, 67.57 percent of the respondents agreed or strongly agreed, with 82.43 percent agreeing that their research skills improved at least slightly as a result of the course. About the same number of respondents mentioned that the course discussion boards and assignments helped them improve their written communication skills $(66.22 \%$ agreed or strongly agreed, $75.68 \%$ agreed at least slightly). Furthermore, 81.08 percent of the respondents reported improved time management skills.

When asked about their perceptions as a result of the course, 93.16 percent of the respondents at least slightly agreed that they felt eager to work hard and achieve results. The same proportion mentioned that they felt they can now perform their job better; 90.42 percent at least slightly agreed that they are enthusiastic about their job, while 84.93 percent reported that they are satisfied with their job. Finally, 87.84 percent of the respondents confirmed that the course accomplished its stated goals with 83.78 percent of the respondents mentioning that their overall learning experience in the course was at least what they had expected.

\subsection{Descriptive Results}

The means, standard deviations, and correlations for talent attributes and skills and talent development outcomes are shown in Tables 1 and 2 respectively. The intercorrelations for the constructs showed that multicollinearity was unlikely to be a problem in regression analyses as no associations between independent variables exceeded .7 other than job motivation and job engagement [27]. The largest correlations between independent variables were observed for job motivation and job engagement $(r=.72)$, suggesting the close relationship between the two variables, and that eagerness to work hard and achieve results (job motivation) has a strong relationship with job enthusiasm (job engagement).

Table 1. Talent Attributes and Skills - Results of Means, Standard Deviations, and Correlations

\begin{tabular}{|l|c|c|c|c|c|}
\hline \multicolumn{1}{|c|}{ Variables } & $\begin{array}{c}\text { Problem } \\
\text { solving }\end{array}$ & Analytical & $\begin{array}{c}\text { Communica- } \\
\text { tion }\end{array}$ & Research & $\begin{array}{c}\text { Time man- } \\
\text { agement }\end{array}$ \\
\hline Mean & 5.58 & 5.86 & 5.62 & 5.78 & 5.58 \\
\hline Standard Deviation & 1.03 & 0.87 & 1.32 & 1.20 & 0.99 \\
\hline Problem solving & 1.00 & & & & \\
\hline Analytical & $0.59^{*}$ & 1.00 & & & \\
\hline Communication & $0.49^{*}$ & $0.36^{*}$ & 1.00 & & \\
\hline Research & $0.50^{*}$ & $0.49^{*}$ & $0.58^{*}$ & 1.00 & \\
\hline Time management & $0.36^{*}$ & $0.52^{*}$ & $0.40^{*}$ & 0.53 & 1.00 \\
\hline
\end{tabular}

${ }^{*} \mathrm{p}<.01$ (two-tailed) 
Table 2. Talent Development Outcomes - Results of Means, Standard Deviations, and Correlations

\begin{tabular}{|l|c|c|c|c|c|}
\hline \multicolumn{1}{|c|}{ Variables } & $\begin{array}{c}\text { Job perfor- } \\
\text { mance }\end{array}$ & $\begin{array}{c}\text { Job satisfac- } \\
\text { tion }\end{array}$ & $\begin{array}{c}\text { Job engage- } \\
\text { ment }\end{array}$ & Job motivation & $\begin{array}{c}\text { Goal attain- } \\
\text { ment }\end{array}$ \\
\hline Mean & 5.75 & 5.66 & 5.89 & 6.21 & 5.74 \\
\hline Standard Deviation & 0.92 & 1.22 & 1.20 & 1.30 & 1.00 \\
\hline Job performance & 1.00 & & & & \\
\hline Job satisfaction & $0.25^{*}$ & 1.00 & & & \\
\hline Job engagement & 0.14 & $0.75^{*}$ & 1.00 & & \\
\hline Job motivation & 0.22 & $0.59^{*}$ & $0.72^{*}$ & 1.00 & \\
\hline Goal attainment & $0.63^{*}$ & $0.52^{*}$ & $0.33^{*}$ & $0.41^{*}$ & 1.00 \\
\hline
\end{tabular}

${ }^{*} \mathrm{p}<.01$ (two-tailed)

\subsection{Multiple Regression Analyses}

To examine which of the talent attributes and skills contributes to overall learning, a multiple regression analysis was conducted. The five independent variables (problem solving, analytical, communication and research skills and time management skills) and the dependent variable (overall learning experience) were entered simultaneously into a multiple regression analysis. The standardized estimates of the regression coefficients are presented in Table 3 and the significant predictors are shown in Figure 1.

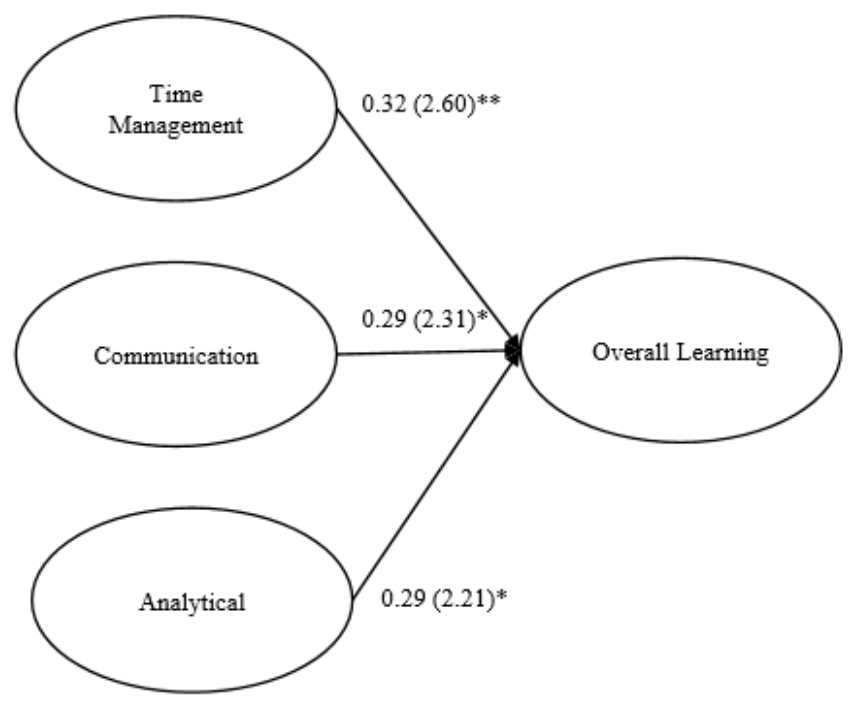

Fig. 1. Relationship between talent attributes and skills and overall learning (Numbers in parentheses represent t-values associated with each coefficient with significance; ${ }^{*} \mathrm{p}<.05$, $* * \mathrm{p}<.01, * * * \mathrm{p}<.001)$ 
Table 3. Regression Analysis of Skills on Overall Learning

\begin{tabular}{|c|c|c|}
\hline & \multicolumn{2}{|c|}{ DV: Overall Learning } \\
\hline & Beta value & t-value \\
\hline Problem solving & .17 & 1.32 \\
\hline Analytical & .29 & $2.21 *$ \\
\hline Communication & -29 & $-2.31^{*}$ \\
\hline Research & .11 & 0.85 \\
\hline \multirow[t]{2}{*}{ Time management } & .32 & $2.60 * *$ \\
\hline & \multicolumn{2}{|c|}{$\begin{array}{c}\mathrm{F}(5,67)=8.122^{* * *} \\
\text { Adj } \mathrm{R}^{2}=.331\end{array}$} \\
\hline
\end{tabular}

${ }^{*} \mathrm{p}<.05,{ }^{* *} \mathrm{p}<.01,{ }^{* * *} \mathrm{p}<.001$

As seen in Table 3, time management skills emerged as the best predictor of overall learning $(\beta=.32, \mathrm{p}<.01)$, followed by communication and analytical skills, explaining 33.1 percent of the variance. Problem solving and research skills did not emerge as predictors, possibly because the talent employees are already well equipped with these two skills. As such, H1 is partially supported, as corporate e-learning can be used to develop talent attributes and skills such as analytical, communication, and time management skills.

To further examine which of the skills contributes to talent development outcomes, a multiple regression analysis was conducted. The five independent variables (problem solving, analytical, communication and research skills and time management skills) and the respective dependent variables (employee job performance, satisfaction, engagement, and motivation) were entered into separate multiple regression analyses. The standardized estimates of the regression coefficients are presented in Tables 4 and 5 and the significant predictors are shown in Figure 2.

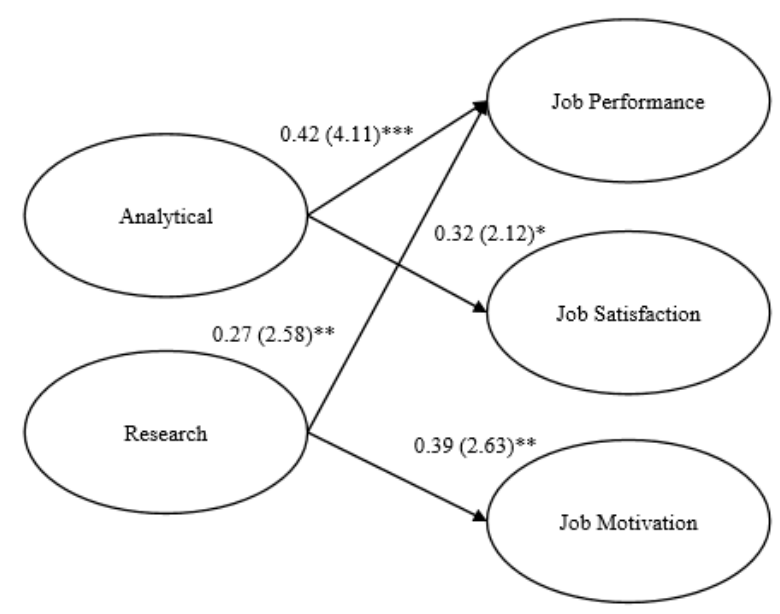

Fig. 2. Relationship between talent attributes and skills and talent development outcomes (Numbers in parentheses represent $t$-values associated with each coefficient with significance; $\left.{ }^{*} \mathrm{p}<.05,{ }^{*} \mathrm{p}<.01,{ }^{* * *} \mathrm{p}<.001\right)$ 
Table 4. Regression Analyses of Skills on Talent Development Outcomes - Job Performance and Satisfaction

\begin{tabular}{|l|c|c|c|c|}
\hline & \multicolumn{2}{|c|}{ DV: job performance } & \multicolumn{2}{c|}{ DV: job satisfaction } \\
\hline & Beta value & $\boldsymbol{t}$-value & Beta value & t-value \\
\hline Problem solving & .16 & 1.62 & -.27 & -1.81 \\
\hline Analytical & .42 & $4.11^{* * *}$ & .32 & $2.12^{*}$ \\
\hline Communication & -.05 & -.53 & .22 & 1.55 \\
\hline Research & .27 & $2.58 * *$ & .16 & 1.05 \\
\hline Time management & .18 & 1.92 & .00 & -.00 \\
\hline & \multicolumn{2}{|c|}{$\mathrm{F}(5,66)=23.39 * * *$} & \multicolumn{2}{c|}{$\mathrm{F}(5,66)=3.12 * *$} \\
Adj $\mathrm{R}^{2}=.612$ & \multicolumn{2}{|c|}{$\mathrm{Adj}=.130$} \\
\hline
\end{tabular}

$* \mathrm{p}<.05, * * \mathrm{p}<.01, * * * \mathrm{p}<.001$

Table 5. Regression Analyses of Skills on Talent Development Outcomes - Job Engagement and Motivation

\begin{tabular}{|l|c|c|c|c|}
\hline & \multicolumn{2}{|c|}{ DV: job engagement } & \multicolumn{2}{c|}{ DV: job motivation } \\
\hline & Beta value & $\boldsymbol{t}$-value & Beta value & t-value \\
\hline Problem solving & -.13 & -.86 & .05 & .38 \\
\hline Analytical & .00 & .02 & .12 & .82 \\
\hline Communication & .06 & .39 & -.04 & -.30 \\
\hline Research & .29 & 1.85 & .39 & $2.63 * *$ \\
\hline Time management & .21 & 1.51 & .03 & .20 \\
\hline & \multicolumn{2}{|c|}{$\mathrm{F}(5,66)=2.872 *$} & \multicolumn{2}{c|}{$\mathrm{F}(5,66)=4.16^{* * *}$} \\
& \multicolumn{2}{|c|}{ Adj $\mathrm{R}^{2}=.116$} & \multicolumn{2}{c}{$\mathrm{R}^{2}=.182$} \\
\hline
\end{tabular}

$* \mathrm{p}<.05, * * \mathrm{p}<.01, * * * \mathrm{p}<.001$

As reported in Table 4, analytical skills emerged as the best predictor of job performance $(\beta=.42, p<.001)$, along with research skills, explaining 61.2 percent of the variance. For job satisfaction, only analytical skills emerged as important $(\beta=.32, \mathrm{p}<$ $.05)$. As seen in Table 5, the only predictor of job motivation is research skills $(\beta=$ $.39, \mathrm{p}<.01)$, with the rest of the talent attributes and skills appearing as insignificant. The results showed partial support for $\mathrm{H} 2$, as corporate e-learning can lead to talent development outcomes such as job performance, job satisfaction, and job motivation.

\section{$5 \quad$ Discussion and Managerial Implications}

This study examined the effectiveness of corporate e-learning in the context of talent management on a global scale. The findings suggest that corporate e-learning can be used to develop talent attributes and skills such as problem solving, analytical, communication, research, and time management skills. Specifically, time management, communication, and analytical skills are important predictors of overall corporate e-learning experience, with time management emerging as the best predictor. This is not surprising given the busy work schedules of the talent employees. This is reinforced by findings from a McKinsey study of 1,500 executives across the globe, 
which found that nearly half of the respondents admitted that they were not concentrating sufficient on guiding the strategic direction of the business [16].

Even though a major component of the learning is conducted in asynchronous mode, some of the learners find it hard to dedicate time during the three weeks period per module to read the online content, watch the faculty videos, and engage in peer interactions within the discussion boards due to their busy work commitment. In view of this, the company should provide relevant tools and incentives to help talents better manage their work-study balance, such as creating time budgets and having formal processes for time allocation. For example, the company can allow flexible work arrangement or give employees time off to focus on their study during critical periods, i.e., towards the end of the discussion board deadlines and during the final project completion week. In addition, the company can also work with the talents to establish a time budget for priority initiatives during their study, or provide high quality administrative support to help enhance the effectiveness of the talents' allocation of time during their study [16].

In terms of job performance, analytical and research skills emerged as important predictors, with the former being the better predictor. According to Wong [28], analytical skills might be related to job performance, and this positive relationship is stronger for high-level jobs versus simple and repetitive jobs, as high-performing talent often need to handle complicated problems at work. Given that the sample for this study includes A-players, high performers or high potentials, the effect of analytical skills on job performance emerged as significant most likely due to the increased complexity of the jobs involved.

For job satisfaction, only analytical skills emerged as important, while for job motivation, only research skills emerged as important. The emphasis on analytical skills is highlighted in a study by the American Management Association which reported that 82 percent of company leaders understand the importance of analytical skills in the future and believe that analytical skills is important for senior leaders [15]. In order to enhance the talent's overall e-learning experience, job performance, job satisfaction, and job motivation, Human Resource managers should pay attention to these attributes and skills in the design of their global talent development program (i.e. what competencies to develop).

The findings show that corporate e-learning can lead to talent development outcomes such as job performance, job satisfaction, and job motivation. As such, global companies can enroll their A-players, high performers or high potentials into relevant corporate e-learning programs that can be used to effectively address the training challenges of a scattered workforce and improve coordination among internal and outside collaborators and partners in complex business processes and projects. Participation in such e-learning programs can also generate a major competitive advantage for the organization in terms of increased employee job performance, job satisfaction, and job motivation, which leads to improved customer satisfaction and better employee retention, and finally increased organizational performance [11]. 


\section{$6 \quad$ Limitations and Future Research}

The sample for this study was limited to a multinational IT services provider. Future research should extend the scope of data collection to include talents from a variety of organizations, as well as a variety of geographies and industries to further investigate the generalizability of these findings. Given the limited theoretical and empirical works in other contexts, future studies should also examine different organizational contexts such as large domestic companies as well as small and medium size enterprises. This study measured perceptions of e-learning rather than actual impact on e-learning. Future studies should include actual measures such as return-oninvestment and work performance. In addition, this study found high correlations between job engagement and job motivation. Future studies should examine the interrelationship between these two constructs in order to better understand the effectiveness of corporate e-learning in global talent management. Specifically, several research questions emerge. What role does corporate e-learning play in terms of global talent management in the long run? How can organizations develop their e-learning systems into a comprehensive and collaborative communication channel? These questions may provide interesting topics for further study.

\section{$7 \quad$ References}

[1] D. Egerová, "Talent management: Towards the new perspectives", Problems on Management in the $21^{\text {st }}$ Century, vol. 9, no. 2, pp. 114-116, 2014.

[2] V. Vaiman et al., "Talent management decision making”, Management Decision, vol. 50, pp. 925-941, 2012. https://doi.org/10.1108/00251741211227663

[3] P. Cheese et al., "The new talent equation", Outlook. The J. of High-Performance Business, pp. $1-10,2009$.

[4] R. S. Schuler et al., "Global talent management and global talent challenges: Strategic opportunities for IHRM", J. of World Business, vol. 46, pp. 506-516, 2011. https://doi.org/10.1016/j.jwb.2010.10.011

[5] S. Nilsson and P. E. Ellström, "Employability and talent management: Challenges for HRD practices", European J. of Training and Development, vol. 36, no. 1, pp. $26-45$, 2012. https://doi.org/10.1108/03090591211192610

[6] P. Kumar and U. Gulla, "Corporate e-learning: Possibilities, promises, and realities”, J. of Library and Information Technology, vol. 31, no. 3, pp. 179-188, 2011. https://doi.org/10.14429/djlit.31.3.987

[7] E. Gallardo-Gallardo et al., "What is the meaning of 'talent' in the world of work?", Human Resource Management Review, vol. 23, no. 4, pp. 290-300, 2013. https://doi.org/10.1016/j.hrmr.2013.05.002

[8] M. Thunnissen et al., “A review of talent management: Infancy or an adolescence?", The International J. of Human Resource Management, vol. 24, no. 9, pp. 1744-1761, 2013. https://doi.org/10.1080/09585192.2013.777543

[9] R.E. Lewis and R. J. Heckman, "Talent management: A critical review”, Human Resource Management Review, vol. 16, pp. 139- 154, 2006. https://doi.org/10.1016/j.hrmr.20 $\underline{06.03 .001}$ 
[10] M. Moeller et al., "Global talent management and inpatriate social capital building: A status inconsistency perspective", The Int. J. of Human Resource Management, vol. 27, no. 9, pp. 991-1012, 2016. https://doi.org/10.1080/09585192.2015.1052086

[11] H. Scullion and D. G. Collings, Global Talent Management. Routledge, London and New York, 2011.

[12] P. Cheese et al., The Talent Powered Organization: Strategies for Globalization, Talent Management and High Performance, Kogan Page, London, 2008.

[13] T. N. Garavan et al., "Mapping talent development: definition, scope and architecture", European J. of Training and Development, Vol. 36 No. 1, pp. 5-24, 2012. https://doi.org/10.1108/03090591211192601

[14] B. Scott, "Graduate attributes and talent perceptions: Reflections of the first year of graduate employment", Int. J. of Employment Studies, Vol. 22 No. 1, pp. 39-59, 2014.

[15] F. Stone, "Companies see need to build analytical skills in their organizations: A study of analytical skills in the workforce", American Management Association, 2014, available at http://www.amanet.org/training/articles/companies-see-need-to-build-analytical-skills-intheir-organizations.aspx, (accessed 16 June 2017).

[16] F. Bevins, and A. De Smet, "Making time management the organization's priority", McKinsey Quarterly, January, 2013, available at http://www.mckinsey.com/businessfunctions/organization/our-insights/making-time-management-the-organizations-priority, (accessed 16 June 2017).

[17] P. Naithani, "Overview of work-life balance discourse and its relevance in current economic scenario", Asian Social Science, vol. 6, no. 6, p. 148, 2010. https://doi.org/10.5539/ass.v6n6p148

[18] S. Shagvaliyeva and R. Yazdanifard, "Impact of flexible working hours on work-life balance", American J. of Industrial and Business Management, vol. 4, pp. 20-23, 2014. https://doi.org/10.4236/ajibm.2014.41004

[19] G. K. Stahl et al., "Six principles of effective global talent management", MIT Sloan Management Review, vol. 53, pp. 24-32, 2012.

[20] D. W. De Long and T. Davenport, "Better practices for retaining organizational knowledge: Lessons from the leading edge", Employee Relations Today, vol. 30, no. 3, pp. 51-63, 2003. https://doi.org/10.1002/ert.10098

[21] J. Schramm, "Future focus: Targeting retention", HR Magazine, vol. 51, no. 9. p. 216, 2006.

[22] M. Messmer, "Four keys to improved staff retention", Strategic Finance, vol. 88, no. 4, pp. 13-14, 2006.

[23] K. Schofield, On-line learning: Case studies of the corporate experience", OVAL Research Working Paper 02-01, University of Technology, Sydney, 2002.

[24] K. Anderson and G. Woodill, "Calculating the ROI of corporate eLearning", Operitel Corporation, 2004, available at http://www.operitel.com/lib/pdf/wp roi.pdf, (accessed 16 June 2017).

[25] H. Brandon, Web-based Training Cookbook. Wiley, New York, NY, 1997.

[26] J. D. Fletcher, Multimedia Review, Spring, pp. 33-42, 1991.

[27] B. G. Tabachnick and L. S. Fidell, Using Multivariate Statistics, Allyn and Bacon, Needham Heights, MA, 2001.

[28] C. S. Wong, Emotional Intelligence at Work: 18-year Journey of a Researcher, Routledge, Abingdon, Oxon, 2015. 
Paper-Examining the Effectiveness of Corporate E-Learning in Global Talent Management

\section{Authors}

Amy Wong is with GlobalNxt University, Kuala Lumpur, Malaysia.

Karin Sixl-Daniell is with MCI University of Applied Sciences, Innsbruck, Austria.

Article submitted 16 June 2017. Published as resubmitted by the authors 03 August 2017. 